\title{
A FISKÁLIS TRANSZPARENCIA ÉS A TÁRSADALMI ELSZÁMOLÁSI MÁTRIX KITERJESZTÉSE
}

\author{
Dr. Czagány László, kandidátus \\ egyetemi docens, Szegedi Tudományegyetem Mérnöki Kar
}

\begin{abstract}
Summary
Enhancing transparency is a highly current and important task in improving public finances. In the most general sense, fiscal transparency means, that those economic actors which use data on the state and changes of the government budget to build their decisions on should be able to acquire these data in the appropriate quantity, quality and structure. One fundamental transparency-problem is the demarcation of macroeconomic actors viz. the sectors of the economy. This study aims at contributing to the solution of this problem by extending the social accounting matrix compiled in accordance with the guidelines of the ESA and SNA.
\end{abstract}

\section{A fiskális transzparencia szükségessége}

Az államháztartás fejlesztésének egyik rendkívül aktuális feladatköre a transzparencia, az átláthatóság javítása. Legáltalánosabb értelemben a fiskális transzparencia azt jelenti, mindazok a gazdasági szereplök, akik döntéseik megalapozásához felhasználják a költségvetés helyzetének, változásainak adatait, kellő mennyiségben, szerkezetben, minőségben kapjanak információkat. A felhasználók a gazdaságpolitika irányítói, a vállalatok és egyéb intézmények, befektetők, a háztartások stb. Az elmúlt évtized szakirodalma föként a makrogazdasági döntések megalapozhatósága szempontjából vizsgálta a transzparencia problémáját és nagy hangsúlyt kapott a nemzetközi rendszerekhez viszonyított kompatibilitás is. Ez utóbbi törekvéseket esetenként segítették, más esetekben megnehezitették az SNA, az IMF által létrehozott pénzügyi statisztikai rendszer, a GFS és az európai rendszer az ESA nemritkán egymásnak ellentmondó direktívái.

Talán általánosítható az a vélemény, hogy a fiskális transzparencia megteremtésének elsỏ szintje az államháztartás konzekvens szabályozása, vagyis az államháztartási funkciók egyértelmü tisztázása, ezzel releváns funkcionális és intézményi elhatárolások, vagyis az államháztartáson belüli világos, ha úgy tetszik transzparens munkamegosztás kialakítása. A transzparencia második szintje, a számviteli-statisztikai szint csak az elöbbinek a tükröződése lenne. A valóságban jelenleg inkább az a helyzet, hogy a szabályozási hiányosságokat a statisztika jó értelemben vett kreativitásával igyekszünk korrigálni. Olyan körülmények között, amikor az államháztartás keretein kívül is folyik fiskális tevékenység, másrészt az államháztartási rendszer intézményei a vállalati szektor funkcióinak egy részét is felvállalja, igen nehéz a gazdaságpolitikai döntésekhez szükséges tisztánlátás feltételeit megteremteni. Manapság tudós statisztikusok rendkívül színvonalas vitákat tudnak folytatni olyan alapvető kérdésekben, hogy mekkora az ország adósságállománya, a költségvetés deficitje, mennyi a magánfogyasztás stb.

Az egyetemi makroökonómiai kurzusokon minket, az elméleti közgazdaságtan oktatóit látszólag nem érintenek közvetlenül a transzparencia gyakorlati kérdései. Az elméleti modellek múködésének nem feltétele a pontos statisztikai mutatók ismerete, a modellfeltevésekkel könnyen megoldhatjuk azokat a problémákat, ami a statisztikusok nem, vagy csak nagyon ravasz módszerekkel tudnak megoldani. Függvényeink, görbéink alapesetben algebrai szimbólumokkal is müködnek; ha pedig numerikusan is illusztrálni 
akarjuk mondanivalónkat, akkor mondhatjuk például, hogy legyen $\mathrm{G}=200$, az adó pedig $\mathrm{T}=50+0,2 \mathrm{Y}$. Egy ilyen kényelmes helyzetben nem váltam az államháztartási statisztika és számvitel aktív mủvelöjévé, $s$ rövid referátumomban is csak a makroökonómia egyetemi oktatása szempontjából érintek néhány kérdést.

\section{Az állami szektor elhatárolásának problémái}

Egyfajta alapvető elméleti transzparencia-probléma például a makrogazdasági szereplök, vagyis a nemzetgazdasági szektorok elhatárolása. A hagyományos makroökonómia tananyagok négyszektoros modelljének szereplöi: a vállalati, a háztartási és állami szektor, valamint a Külföld. Egy széles körben használt Makroökonómia tankönyv [Meyer D., Solt $\mathrm{K}]$ az állami szektort így definiálja: "Ide tartoznak a nemzetgazdasági szintü feladatokat ellátó intézmények, amelyek nem a piacon keresztül elégítenek ki szükségleteket, kiadásaikat adókból és egyéb állami bevételekből fedezik." "A vállalati szektor azon gazdasági egységek összessége, amelyek értékesítés céljából árukat (termékeket és szolgáltatásokat) termelnek. Költségeiket pénzbevételeikböl fedezik, tevékenységük célja a profitszerzés." A tankönyv a háztartási szektort két részre osztja: a magánháztartásokra és a nonprofit szervezetekre. A nonprofit szektor a definíció szerint a magánháztartások közösségi fogyasztásának színhelye.

Ezek a megközelítések nem csupán egy vảjt fưlü statisztikus igényeihez képest elégtelenek, hanem az elméleti közgazdaságtan modelljei is differenciáltabb elhatárolásokat kívánnak. A definíciókban keverednek az intézményi és a funkcionális szempontok. A kétféle szemlélet között következetes alkalmazás esetén igen jelentős eltérések lehetnek, Ennek egyik oka, hogy az államháztartási intézményeken belül számos nem klasszikusan államháztartási feladatot ellátnak, másik oka az, hogy az állam allokatív szerepe részben a piaci körbe kerül. Legkevésbé az jelenik meg a fenti definiciókban, hogy államháztartási feladatokat igen nagy számban az államháztartás szervezetén kívül látnak el, ezek az un. kvázi fiskális tèvékenységek.

Az SNA-ban a funkcionális osztályozás nem más, mint a szervezeti megközelítésü államháztartásnak (és a nonprofit szektornak) a felbontása bizonyos tevékenységi kategóriákra. A baj az, hogy nem történik meg az államháztartáson kivüli, fiskálisnak tekinthető funkciók számbavétele a többi szektorban. A tevékenységi kategóriák alapján sem teljesen határolhatóak el a tisztán fiskális funkciók, hiszen ahhoz például az egészségügyet és az oktatást is szét kellene bontani. Mindennek az a következménye, hogy az SNA adatbázisából nem lehet funkcionális szemléletben előállítani a fiskális jelzőszámokat. Erre csak további, számviteli adatokból (pl. az érintett szervezetek eredmény-kimutatásából) kiinduló vizsgálatok alapján kerülhet sor.

Az SNA intézményi besorolása alapvetően az államháztartás hagyományos alrendszereit foglalja magába, kivéve azokat a vállalthoz hasonló módon, megfelelő minőségủ számvitellel mủködő ún. kvázi vállalatokat, amelyek szolgáltatásukat szignifikáns ár mellett értékesítik. Az Európai Számlák Rendszere (ESA) ezt a megközelítés operacionalizálva úgy húzza meg az államháztartás határait, hogy a szolgáltatás költségeinek 50\%-át fedezi-e az ár. Ha nem, akkor az államháztartáshoz sorolja a szervezetet, ha igen, akkor a vállalati szektorhoz, bár ezek a szervezetek persze kvázi vállalatok.

Rendszerezve a termékeket, szolgáltatásokat nyújtó szervezetek besorolási szempontjait a következő mátrixot kaphatjuk: 


\section{1. ábra: A magánszféra és a közszféra elhatárolása}

\begin{tabular}{|c|c|c|c|}
\hline \multirow{2}{*}{$\begin{array}{c}\text { Fedezi-e az ár a } \\
\text { költségek } 50 \% \text {-át? }\end{array}$} & \multicolumn{2}{|c|}{ Magánszféra } & Közszféra \\
\hline & Profitorientált & Non & \\
\hline Igen & Vállalati szektor & Nonprofit vállalatok & $\begin{array}{l}\text { Közszolgáltató } \\
\text { vállalatok }\end{array}$ \\
\hline Nem & & Háztartási szektor & Államháztartás \\
\hline
\end{tabular}

Forrás: Saját összeállitás az ESA ajánlásai alapján

Besorolásomban némelyik szektor elnevezése a tömörítésre való törekvés közepette kétségtelenül pontatlan, talán önkényes is, de mindenképpen magyarázatra szorul, s nyitott vagyok az elnevezések javítására vonatkozó javaslatokkal szemben.

A "Nonprofit vállalatok" kétségtelenül legfeljebb kvázi vállalatok. Ide tartoznak azok a közfeladatokat átvállaló magánszervezetek, amelyek természetesen bevételeikböl fedezik kiadásaikat, de egyrészt deklarált és valóságos céljuk nem a profit, másrészt a szolgáltatások dijai a költségeknek nagyobb részét fedezik, de nem az egészet, a dijakkal nem fedezett költséget más szektorból származó transzferekkel, támogatásokkal, adományokkal fedezik. Példa lehet erre egy sportkör, vagy egy egyházi iskola.

A "Köszolgáltató vállalatok" szintén kvázi vállalatok, hatékonyságuk megitélésének fö kritériuma nem a profit, hanem a tevékenységi körbe tartozó feladatok ellátásának szinvonala. Tipikus esetben szintén transzferekkel kell kiegészíteni árbevételeiket. Lényeges különbség az elöbbi "Nonprofit vállaltokkal" szemben, hogy ezek a transzferek kizárólag az állami költségvetésböl származnak. Tipikus példa lehet erre a MÁV.

A Háztartások szektorba sorolt nonprofit szervezetek dijbevételeikböl a szolgáltatások költségeinek csak kis hányadát fedezik, ezért - az ESA logikájának megfelelöen - a dijbevételeket eleve a háztartási szektoron belüli transzfernek tekintjük, így ez a konszolidált szektormérlegben meg sem jelenik: a háztartások magánfogyasztásra felhasználható jövedelme csökken, de ugyanennyivel nő a szektoron belüli kőzősségi szolgáltatást nyújtó szervezetek forrása.

\section{A társadalmi elszámolási mátrix kiterjesztése}

A fenti összefuggések figyelembevételével a makrogazdasági körforgás sémája differenciáltabban jelenithetö meg. Azért, hogy az átláthatóbb legyen a séma csak az eredetileg háromszektoros modell kiterjesztését vizsgáljuk meg. A körforgás sémáját az alapfokú makroökonómiai tankönyvek formailag kétféleképpen szokták megjeleníteni: vagy a szektorok számláin a kettős könyvvitel módszerével, vagy mátrixba rendezve. Válasszuk mi az utóbbi eljárást. A három szektoros gazdaság elszámolási mátrixa a kiterjesztés elött: 


\section{2. ábra: A társadalmi elszámolási mátrix}

\begin{tabular}{|l|c|c|c|c|c|}
\hline & $\begin{array}{c}\text { Hazai } \\
\text { össztermék }\end{array}$ & Vállalatok & Háztartások & Állam & Tökepiac \\
\hline $\begin{array}{l}\text { Hazai } \\
\text { össztermék }\end{array}$ & & & $\mathrm{C}$ & $\mathrm{G}$ & $\mathrm{I}$ \\
\hline Vállalatok & $\mathrm{Y}$ & & & & \\
\hline Háztartások & & $\mathrm{W}$ & & $\mathrm{TR}$ & \\
\hline Állam & & $\mathrm{T}_{\mathrm{V}}$ & $\mathrm{T}_{\mathrm{H}}$ & & \\
\hline Tókepiac & & $\mathrm{S}_{\mathrm{V}}$ & $\mathrm{S}_{\mathrm{H}}$ & $\mathrm{S}_{\dot{\mathrm{A}}}$ & \\
\hline
\end{tabular}

Forrás: Hall R.E.-Taylor j.B.:Makroökonómia (KJK, 1999) alapján

A kiterjesztés lényeges elemei:

A makroszintü kibocsátást megbontottam a három "termelö" szektorra:

$$
\mathbf{Y}=\mathbf{Y}_{\mathbf{v}}+\mathbf{Y}_{\mathrm{N}}+\mathbf{Y}_{\mathbf{K}}
$$

A háztartási szektorba sorolt nonprofit szervezetek szolgáltatásának értéke nem növeli a makroszintü kibocsátást, hiszen azt a háztartáson belüli transzfernek minősítettük.

A végső felhasználási formák közül a magánfogyasztást és a költségvetési vásárlásokat hasonló módon felbontottam azzal a kiegészitéssel, hogy a nonprofit vállalatok és a közszolgáltatók produktumának értékét csak részben fizeti meg a vevő (ezt P-vel jelöltem), másik részét a költségvetés fizeti meg (D). Így:

$$
\begin{array}{r}
\mathbf{C}=\mathbf{C}_{\mathrm{V}}+\mathbf{C}_{\mathrm{N}}+\mathbf{C}_{\mathrm{K}}=\mathbf{C}_{\mathrm{V}}+\left(\dot{\mathrm{P}}_{\mathrm{NH}}+\mathbf{D}_{\mathrm{Nh}}\right)+\left(\mathbf{P}_{\mathrm{KH}}+\mathbf{D}_{\mathrm{KH}}\right) \\
\mathbf{G}=\mathbf{G}_{\mathbf{V}}+\mathbf{G}_{\mathrm{N}}+\mathbf{G}_{\mathbf{K}}=\mathbf{G}_{\mathrm{V}}+\left(\mathbf{P}_{\mathrm{NA}}+\mathbf{D}_{\mathrm{NA}}\right)+\left(\mathbf{P}_{\mathrm{KH}}+\mathbf{D}_{\mathrm{KH}}\right)
\end{array}
$$

Érdemes még megfigyelni a háztartások jövedelmi mérlegét mérlegét:

$$
\sum \mathbf{W}+\mathbf{T R}_{\mathrm{soc}}+\sum \mathbf{T} \mathbf{R}_{\mathrm{H}}=\mathbf{C}_{\mathrm{V}}+\sum \mathbf{P}_{\mathrm{H}}+\mathbf{T} \mathbf{R}_{\mathrm{NH}}+\mathbf{T}_{\mathrm{H}}+\mathbf{S}_{\mathrm{H}}
$$

Vagyis a háztartások bevételei: a különböző termelö szektoroktól kapott tényezőjövedelmek, a szociális jellegü transzferek, továbbá a háztartások körébe sorolt nonprofit szervezeteknek nyújtott direkt támogatások. A kiadási oldalon a nonprofit vállalatok és a közszolgáltató vállalatok szolgáltatásai fejében csak azok értékénél kisebb díjtételek terhelik a háztartásokat, viszont szerepel a mérlegben a nonprofit vállalatoknak nyưjtott egyoldalú támogatás.

A mátrix túl nagy ahhoz, hogy minden egyes elemét és mérlegét itt megtárgyaljuk, az érdemi tanulmányozás és esetleges bírálat minden bizonnyal egy kinyomtatott váitozatot kíván. Erre biztatom és kérem is a kollegákat. A referátum alaptémájához visszatérve azonban talán érdemes szemügyre venni a költségvetési egyenleg összetevőit: (Persze ebből a mátrixból csak az elsődleges egyenleget formulázhatjuk, a tőketranszferek, adósságszolgálati kötelezettségek stb. hatása differenciálja a képet)

$$
\mathbf{S}_{\hat{A}}=\sum \mathbf{T}-\left(\mathbf{G}_{\mathbf{V}}+\sum \mathbf{P}_{\hat{A}}+\sum \mathbf{D}_{\hat{A}}+\mathbf{T} \mathbf{R}_{\mathrm{NA}}+\mathbf{T} \mathbf{R}_{\mathrm{HK}}+\mathbf{T} \mathbf{R}_{\mathrm{SOC}}\right)
$$




\section{3. ábra: A társadalmi elszámolási mátrix kiterjesztése}

\begin{tabular}{|c|c|c|c|c|c|c|c|}
\hline & $\begin{array}{c}\text { Hazai } \\
\text { összterm. }\end{array}$ & Vállalatok & $\begin{array}{l}\text { Nonprofit } \\
\text { vállalatok }\end{array}$ & $\begin{array}{l}\text { Közszol- } \\
\text { gáltatók }\end{array}$ & $\begin{array}{l}\text { Háztar- } \\
\text { tások }\end{array}$ & Állam & Tökepiac \\
\hline $\begin{array}{l}\text { Hazai } \\
\text { összterm. }\end{array}$ & & & & & $\begin{array}{c}\mathrm{C}_{\mathrm{V}} \\
\mathrm{P}_{\mathrm{NH}} \\
\mathrm{P}_{\mathrm{KH}}\end{array}$ & $\begin{array}{c}\mathrm{G}_{\mathrm{V}} \\
\mathrm{D}_{\mathrm{NH}} \\
\mathrm{D}_{\mathrm{KH}} \\
\mathrm{P}_{\mathrm{N} \dot{A}}+\mathrm{D}_{\mathrm{N} \dot{A}} \\
\mathrm{P}_{\mathrm{K} \dot{A}}+\mathrm{D}_{\mathrm{K} \dot{A}}\end{array}$ & I \\
\hline Vállalatok & $Y_{V}$ & & & & & & \\
\hline $\begin{array}{l}\text { Nonprofit } \\
\text { vállalatok }\end{array}$ & $Y_{N}$ & $\mathrm{TR}_{\mathrm{NV}}$ & & $\mathrm{TR}_{\mathrm{NK}}$ & $\mathrm{TR}_{\mathrm{NH}}$ & $\mathrm{TR}_{\mathrm{NA}}$ & \\
\hline $\begin{array}{l}\text { Közszol- } \\
\text { gáltatók }\end{array}$ & $\mathrm{Y}_{\mathrm{K}}$ & & & & & & \\
\hline $\begin{array}{l}\text { Háztar- } \\
\text { tások }\end{array}$ & & $\begin{array}{c}\mathbf{W v} \\
\mathrm{TR}_{\mathrm{HV}}\end{array}$ & $\begin{array}{c}W_{N} \\
T_{\mathrm{HN}}\end{array}$ & $\begin{array}{r}W_{K} \\
T_{R_{H K}}\end{array}$ & & $\begin{array}{l}\mathrm{TR}_{\text {SOC }} \\
\mathrm{TR}_{\mathrm{HK}}\end{array}$ & \\
\hline Állam & & Tv & $\mathrm{T}_{\mathrm{N}}$ & $T_{K}$ & $T_{H}$ & & \\
\hline Tökepiac & & $\mathrm{S}_{\mathrm{V}}$ & $\mathrm{S}_{\mathrm{N}}$ & $\mathrm{S}_{\mathrm{K}}$ & $S_{H}$ & $\mathrm{~S}_{\dot{A}}$ & \\
\hline
\end{tabular}

Forrás: Saját összeállitás

\section{A kvázi fiskális tevékenységek és a transzparencia}

A fiskális transzparencia gondjaival kapcsolatban a referátum elején már beszéltem az ún. kvázi fiskális tevékenységekröl. Ez a mátrix persze nem tudja érzékeltetni a kvázi fiskális tevékenységek terepét. A kvázi fiskális tevékenységet az államháztartáson kívüli szervezetek végzik, $s$ e tevékenységekkel kiegészítik a költségvetési redisztribúciót. A transzparens megoldás az lenne, ha a fiskális szabályozás lehetővé sem tenné ezeket a tevékenységeket. Amennyiben a gyakorlatban létezik ilyen, akkor ezt a statisztikusoknak feltétlenül mérni kell, az elméleti közgazdaságtan müvelöinek pedig be kell építeni modelljeikbe. Miért szükséges a kvázi fiskális tevékenység figyelembe vétele

- mert funkcionális megközelítésben ezzel az államháztartási szektor terjedelmét korrigálni kell.

- mert az állam feltételes kötelezettségeit óriási, gyakran fedezetlen mértékben növelheti, az adósságállománynál számolni kell vele

- mert a kvázi fiskális deficit a monetáris mozgástér fontos tényezöje lehet, a monetáris politika keresleti hatásának vizsgálatánál figyelembe kell venni

- a kvázi fiskális támogatások illetve adók torzitják a forrásallokációt

A kvázi fiskális tevékenységet végző szervezetek lehetnek pénzügyi és nem pénzügyi szervezetek, a nem pénzügyi szervezetek szerepe általában kevésbé jelentős.

A kvázi fiskális tevékenységre jó példa a vagyonkezelő szervezetek jó néhány akciója az elmúlt évtizedben. Az állami tulajdon privatizációjából származó forrásokat gyakran a költségvetési transzfereket helyettesítő kifizetésekre használták. Az ÁPV Rt. teljesítette például az életjáradékra váltott kárpótlási jegyek utáni kifizetéseket, kárelhárítással kapcsolatos kiadásokat, egyes vállalatok támogatását, bankkonszolidációt stb. 1997-ben feladatokat vett át az agrárreorganizáció és a területfejlesztés terén. 1994-ben az ÁPV Rt. az elkülönített alapok felé teljesített 16 milliárdos bevételét hitelböl teljesítette, mert az adott évi 
privatizációs bevételek nem nyưjtottak rá fedezetet. A hitel formailag nem az államadósságot terhelte.

A pénzügyi szervezeteken belül megkülönböztetett a jegybank helyzete. A monetáris politika és a fiskális politika közötti határvonal korántsem olyan markáns, mint ahogy azt a tankönyvek bemutatják. A jegybank ugyan az államháztartás része, de alapfunkciójára gondolva nem kellene a fiskális jelzószámok közvetlen befolyásolójának tekinteni. A kedvezményes hitelek, az eseti hitelgarancia vállalás, az árfolyam kockázat átvállalása, a kedvezményes refinanszírozás általában nem a hagyományos jegybanki funkciókból következnek, hanem sajátos transzferek.

\section{Irodalomjegyzék:}

Hall. R.E.-Taylor J.B.: Makroökonómia . Közgazdasági és Jogi Könyvkiadó. Budapest, 1999 Meyer D. - Solt K.: Makroökonómia. Aula, Budapest 1999.

Orbán G. - Szapáry Gy.: Magyar költségvetési politika- quo vadis?. Közgazdasági Szemle. 2006. április.

P. Kiss G.: Fiskális transzparencia-jelzőszámok nélkül? In. Botos K.(szerk) Pénzügyek az ezredfordulón. SZTE Gazdaságtudományi Kar Közleményei. 2003. JATE Pressz. Szeged. 2003. 